How to Cite

Mantra, I. B. N., Suparsa, I. N., \& Widnyana, I. W. (2019). Intensive collaborative learning workshop to enhance private teachers' teaching competence. International Journal of Social Sciences, 1(1), 47-51. https://doi.org/10.31295/ijss.v1n1.87

\title{
Intensive Collaborative Learning Workshop to Enhance Private Teachers' Teaching Competence
}

\author{
Ida Bagus Nyoman Mantra \\ Universitas Mahasaraswati Denpasar, Bali, Indonesia \\ Corresponding author email:bagusmantra@unmas.ac.id \\ I Nyoman Suparsa \\ Universitas Mahasaraswati Denpasar, Bali, Indonesia \\ suparsa_nym@yahoo.com \\ I Wayan Widnyana \\ Universitas Mahasaraswati Denpasar, Bali, Indonesia \\ wywid@unmas.ac.id
}

\begin{abstract}
Teachers' teaching professionalism urgently needs to be enhanced especially in designing the learning programs and the teaching and assessment practices. This is due to the fact that learning quality is highly dependent on the professionalism of teachers themselves. Teachers' management skill of learning system needs to be improved continually. The demands of high competencies envisioned in the predesigned syllabus in line with the applicable curriculum. Lesson plans include learning implementation plan, making teaching media, making students' worksheets and designing performance-based assessments and product based assessment, as well as authentic assessments urgently, needs to be improved. The present collaborative workshops and mentoring programs could positively develop teachers' professionalism in conducting the learning process. Therefore teachers can provide a more conducive learning atmosphere to the competence of students.
\end{abstract}

Keywords---collaborative, competence, intensive, teacher, workshop.

\section{Introduction}

The development of life in the era of globalization is characterized by the rapid development of science, science and advanced technology, as well as changes and socio-cultural configurations that are sometimes difficult to predict. This development requires the government, in this case, the Ministry of National Education, to provide increasingly serious and more intensive attention to education. The development of communication technology has made the world seem as though it is without dividing and getting narrower. This is a very difficult challenge for teachers to provide a quality education so that students are able to face global competition (Maba, \& Mantra, 2017; Maba et al., 2017; 2018).

Enhancement of learning quality is a logical consensus from the development of science and technology. Development of science and technology require adjustment and enhancement process in a continual manner (Anif, 2013). This followed with the need to update the strategy and concepts of learning for the improvement of learning. In facing the challenge of the globalization era, teachers are expected always conducting their duties professionally. Teachers are expected to challenge the maximum of learning quality. Teachers' tasks are mainly to educate, teach, guide, direct, train, judge and assess their students (Liliana, 2014; Chávez \& Quijije, 2018). Teachers are expected to able to dominate and utilize all factors related to education so that learning quality is created (Mandokhail, \& Mehwish, 2018). Teachers are the Source of human power dominates science, knowledge and expected technology.

Process of learning in the classroom certainly affects the quality of education in school and the quality of national education. Enhancement of teaching quality in school cannot be separated from various factors affecting learning

ISSN 2632-9409

Received Jan 10, 2018 / Accepted Jun 20, 2018 / Published Jul 05, 2018 
activities in the classroom (Anwar et al., 2013; Anif, 2018). Teachers are expected to be professionally carried out teaching and assessment in order to establish a high quality of learning and promote students active learning (Widiastuti, 2016; 2017). In a manner of micro quality, enhancement is very much related to the behavior of professional teachers in the teaching process (Mustafa, 2008). This is a reflection of the teacher's commitment to control the implementation of values, attitudes, and professionalism in daily teaching.

Enhancement quality in learning especially in field teachers' proficiency in teaching in the classroom is absolutely needed by teachers to educate students properly (Mantra, 2017). There are many students who lack motivation in learning because of the lack of teacher's proficiency in motivating their students with effective learning strategies. Moreover, teachers are expected to use multimedia facilities so that the learning process becomes more interesting for the students. Through improvement programs for the quality of education through collaborative workshops, teachers are able to be the agent of change and having adequate competencies to teach their students in facing the development of the global community (Widiastuti, 2017; Macías et al., 2018).

Most of the problems experienced by teachers directly in the classroom are very complex which includes planning, implementation process, and assessment. On the planning stage, the teacher acknowledges that they experience problems in associating the core learning competencies, basic competences, indicators, and assessment (Widiastuti, 2016; Khaerani, 2016). Based on the results of the interviews, teachers are still lack of the ability about lesson planning, understanding the learning competencies, learning implementation and conducting the appropriate assessment. Moreover, teachers stated that they are not able to vary the learning techniques to be more interesting for the students and to be more effective to improve students' competencies. Therefore the intensive collaborative learning programs were carried to enhance their teaching professionalism with the expectation that they are eventually capable of improving the quality of the learning as an effort to achieve the national education objectives.

\section{Materials and Methods}

The subject of this study was a group of teachers who are currently teaching in various schools in Denpasar, Bali. The participants were selected for specific purposes to enhance their teaching professionalism. Moreover, they were chosen as the subject of the study because their ability in teaching as indicated by initial reflection was still very low. Therefore, immediate programs need to be carried out to solve the problem. This study was classroom action research $(C A R)$ consisted of a cyclical process in which in every cycle there were four interconnected activities such as planning, action, observation, and reflection.

In the planning, the researcher prepared the instructional planning for each session before the present study was conducted in the classroom. In action, the researcher did the teaching and learning process. Meanwhile, in the observation, the researcher carefully observed the learning activities. In this step, the researcher observed the subjects' attitudes and behavior toward the teaching and learning process to see the improvement of the subjects. In reflection, the researcher analyzed the result of post-test and the result of observation.

The teaching and learning process was divided into two cycles. Each cycle consisted of two learning sessions which include four interconnected activities. The four interconnected activities are planning, action, observation, and reflection. The results of reflection and observation from the first cycle were used to revise the planning for the second cycle.

\section{Results and Discussions}

In this classroom action research, the data were collected by administering pre-test, post-test and questionnaire. The aim of administering the pre-test was to examine the subjects' pre-existing ability in conducting classroom teaching practices before the treatment was given. Furthermore, the post-test was used in order to see the extent to which the strategy can improve the teachers' classroom teaching practices.

\section{Pre-cycle}

In the pre-cycle, an initial reflection was conducted by doing interviews with the teachers who taught in nonformal education institutions at the selected classes. The interviews were intended to reveal how the teachers' teaching practices were usually conducted in their classroom, and then direct classroom observations were also conducted. The interviews indicated that the teachers in this study merely employed a traditional method in teaching in which teachers were mainly lecturing and then provided some exercises for the students. Teachers were the main attention during the learning processes were carried out in the classroom. 
The aim of the observations was to find out the real problems faced by the teachers. Based on the observation, the teachers found difficulty in teaching effectively especially in making their students be motivated in learning, designing the learning materials, lesson planning, selecting and employing the learning methods and conducting the authentic assessment. Teachers were insufficiently practicing their students to be independent learners. The observations showed that students strongly relied on teachers' guidance in learning.

Furthermore, a pre-test was carried out to know the pre-existing ability of the teachers in the teaching-learning process. The learning activities were started with the administration of pre-test in the form of short answer questions consisting of 20 test items. The tests were constructed to measure teachers' teaching ability, which was constructed to see the teachers' pre-existing ability in teaching. The result of the pre-test showed that the teachers' teaching was very poor, in which there was no student who could achieve the minimum passing grade. It showed that the teachers' teaching ability needed urgently to be improved.

The mean figure of pre-test as an initial reflection was 4.50. This figure was considered to very low if it is compared with the minimum passing grade which has to be passed by the students, that is 7.00 . Thus, to improve the teachers' teaching ability, intensive collaborative workshops were conducted to improve teachers' teaching practices. The learning sessions were carried out in two cyclic learning processes.

Cycle 1

The teaching cycle was carried out based on the result of the pre-test in which the score of the subject really below the standard minimum passing grade. Thus, an improvement action was planned by integrating intensive collaborative workshops as efforts to improve teachers' teaching ability. This cycle was divided into two learning sessions. Each session consisted of four activities namely planning, action, observation, reflection.

The teaching sessions were prepared for 90 minutes for each session. For the first teaching session, the workshops covered lesson planning, teaching methods, and learning implementation and assessment practices.

After designing the lesson plan, workshop actions were carried out. In each teaching action, there were three main activities namely pre-activity, whilst activity, and post-activity. In pre-activity, the teacher arouses teachers' prior knowledge and link up the teachers' knowledge with the upcoming learning material. While-activity is the main activity of the learning process, meanwhile, post-activity is the concluding activity of learning. The main activity was started by assigning teachers in lesson planning, teaching methods, and learning implementation and assessment practices.

Then, a post-test was administered in the post activity of the lesson in session 2 . The teachers were asked to answer 20 questions related to the learning materials presented during the workshop sessions. The result of post-test 1 showed that teachers' teaching ability improved dramatically. In reflection, the researcher analyzed the result of post-test and the result of observation and post activity. Based on the classroom observation, it showed that teachers in this study were really active to participate in all workshop activities. Additionally, the mean figure of the post-test result was 7.50. Based on the result of these sessions, it was decided to continue this study to the second cycle.

Cycle 2

The second cycle was also conducted in four interconnected activities which were the same as the steps in the first cycle, namely planning, action, observation, and reflection. However, there were some elaborations and revisions of the learning activity and more varied learning materials. In planning, the lesson plan was revised from the lesson plan in the first cycle. The revision was made to make the second cycle more interesting for the participants of this study.

In the second cycle, teachers were engaged in pairs and group learning activities. They were asked to seriously discuss their learning assignments in pairs and discussed them in groups. These types of activities enhanced participants' skill more quickly as well as their social skill. The result of the classroom observation also indicated that participants who were learning in pairs and in groups made the participants really active in learning.

In addition, worksheet for the post-test was administered at the end of the second cycle. In this activity, the posttest was administered at the end of session 2 which consisted of 20 questions in the form of short answer task. The mean figure of the second workshop cycle was 8.50. This indicated there was significant improvement achieved in post-test 2 as all students achieved the minimum passing grade. It meant that the collaborative workshop was very effective to improve the participants' teaching competence. Moreover, the result of the questionnaire showed the responses of the participants were improved positively. 


\section{Conclusion}

Teachers' competence in teaching is the most crucial component for the improvement of teaching quality. The use of intensive collaborative workshop was a very practical and effective approach to improve the teachers' competence in teaching. Teachers were highly active to share and discuss their teaching experiences with their partners and continually improve their teaching competence after a serried of workshop sessions. Therefore, it is highly suggested that intensive collaborative workshop should be more actively used for teachers' development program. The education stakeholders should maximize the training program for teachers' development in order the highest quality of education can be attained and our students become well-equipped to face the rapid development of globalization.

\section{Acknowledgments}

Sincere gratitude was dedicated to all teachers participating the workshops, the head of research center of Mahasaraswati Denpasar University, all lectures, the Dean and the Rector of Mahasaraswati Denpasar University for all supports given during conducting this study.

\section{References}

Anif, S. (2013). Profil Kompetensi Profesional Guru Mapel Biologi Pasca Sertifikasi di Karesidenan Surakarta.

Anif, S., Sutama, S., Prayitno, H. J., \& Idrus, N. B. M. (2019). Effectiveness of Pedagogical Competence: A Development Model through Association of Biology Teachers' Forum. Jurnal Pendidikan IPA Indonesia, 8(1), 22-31.

Anwar, Y., Rustaman, N. Y., \& Widodo, A. (2012). Kemampuan subject specific pedagogy calon guru biologi peserta program pendidikan profesional guru (ppg) yang berlatar belakang basic sains pra dan post workshop. Jurnal Pendidikan IPA Indonesia, 1(2).

Chávez, S. A. R., \& Quijije, K. K. B. (2018). A Challenge for Teachers of Inclusive Higher Education. International Research Journal of Management, IT and Social Sciences, 5(2), 129-135.

Competence Test on Biology Teachers: A Case Study in Surakarta. International Journal of Assesment and Evaluation, 25(2), 15-21.

Khaerani, N. C. (2016). Peningkatan Kompetensi Guru dalam Menyusun RPP melalui Kegiatan IHT (in house training). Jurnal Penelitian Tindakan Kelas, 17(1).

Maba, W. (2017). Teacher's perception on the implementation of the assessment process in 2013 curriculum. International Journal of Social Sciences and Humanities, 1(2), 1-9. https://doi.org/10.29332/ijssh.v1n2.26

Maba, W., \& Mantra, I. B. N. (2017). An analysis of assessment models employed by the Indonesian elementary school teachers. International Journal of Social Sciences and Humanities, 1(1), 39-45. https://doi.org/10.29332/ijssh.v1n1.38

Maba, W., Perdata, I. B. K., \& Astawa, I. N. (2017). Constructing assessment instrument models for teacher's performance, welfare and education quality. International Journal of Social Sciences and Humanities, 1(3), 8896. https://doi.org/10.29332/ijssh.v1n3.59

Maba, W., Perdata, I. B. K., Astawa, I. N., \& Mantra, I. B. N. (2018). Conducting assessment instrument models for teacher competence, teacher welfare as an effort to enhance education quality. International Research Journal of Management, IT and Social Sciences, 5(3), 46-52.

Macías, EIP, Cedeño, HAC, \& Chávez, GMR (2018). Importance of Improving Resilience in Teaching-Learning Process of Students with Disabilities. International Research Journal of Management, IT and Social Sciences , 5 (2), 120-128.

Mandokhail, S., Khan, F. R., \& Malghani, M. (2018). Impact of ESL Learners' Self-Esteem on Their Oral Proficiency. International journal of english linguistics, 8(3), 210-222.

Mantra, I. B. N. (2017). Promoting primary school teachers' competence through dynamic interactive workshop and partnership. International Journal of Linguistics, Literature and Culture, 3(1), 1-6.

Mata, L. (2014). Pedagogical Competencies for Mother-Tongue Teacher Education. Educational Sciences: Theory and Practice, 14(1), 341-352.

Ozden, M. (2008). The Effect of Content Knowledge on Pedagogical Content Knowledge: The Case of Teaching Phases of Matters. Educational sciences: theory and practice, 8(2), 633-645. 
Sri Widiastuti, I. A. (2017). Md. 2017. Teachers' Understanding of Formative Assessment. Jurnal Bahasa dan Seni, 45(1).

Widiastuti, I. A. M. S., \& Md, I. A. (2016). EFL Teachers' Beliefs and Practices of Formative Assessment to Promote Active Learning. The ASIAN EFL Journal, 3. 